Pawel Dziekański, PhD

Department of Economics and Finance Jan Kochanowski University in Kielce

Kielce, Poland

DOI: https://doi.org/10.30525/978-9934-26-028-5-8

\title{
DIVERSIFICATION OF FINANCIAL INDEPENDENCE OF COMMUNES IN THE ŚWIĘTOKRZYSKIE VOIVODESHIP IN 2009-2018
}

\section{Introduction}

Financial independence is one of the principles of local government finances. It consists in providing the local government with appropriate financial resources for the implementation of tasks (Dziemianowicz, Kargol-Wasiluk, Bołtromiuk, 2018). The appropriate level of financial independence determines the level of economic security. Perceived as the ability of communes to use internal resources in such a way that will guarantee undisputed development (Szubrycht, 2006).

The financial situation is and the goal of the commune's activity and the result of previously made decisions and the related development opportunities. Its level is proved by ability to achieve a budget balance or increase the commune's assets, the commune's income level, financial independence of the unit, the amount of investment expenditure, the ability to obtain external funds, the financial result achieved by the commune. The state of finance is a synthetic expression of the economic development potential of each economic entity (Dziekański, Prus, 2020; Stanny, Strzelczyk, 2018).

\section{Research aim and method}

The aim of the article is to analyze the financial independence of communes in the Świętokrzyskie Voivodeship using a synthetic measure. The analyzes were carried out in the system of 102 communes of the Świętokrzyskie Voivodeship. Data from the Local Data Bank of the Central Statistical Office for 2009-2018 were used as source material. 
The study of financial independence means the assessment of a complex trait. It is decided by both economic, legal and financial factors. In order to characterize the financial independence of municipalities, the index of income and expenditure independence, fiscal wealth per capita, tax autonomy, financial interference of the state, self-financing and investment attractiveness were used.

In the process of creating a synthetic feature, the following stages were distinguished: 1) selection of variables describing the tested objects; 2) assessment of the preferences of variables in relation to the phenomenon under consideration (their division into stimulants and destimulants) and standardization according to the method of zero unitarization; 3) determination of a synthetic synetic measure in accordance with the Technique for Order Preference method to make it similar to the ideal solution (TOPSIS) and distances in real space with Euclidean metric for individual objects; 4) division of the studied area into 4 quartile groups and analysis of correlation measures (Kukuła, 2000; Malina, 2004; Behzadian et al. 2012; Dziekański, Pawlik, 2019; Dziekański et al. 2020).

\section{Financial independence of communes}

Communes are obliged to carry out tasks related to the provision of public services, shaping development processes, technical and social infrastructure, public safety and order as well as spatial order and ecology.

The financial situation is understood as the ability to finance tasks in the given socio-economic and institutional conditions and the ability to generate sufficient financial resources necessary to settle liabilities in a given period. Its conditions are shaped by the area in which municipalities exist (e.g. the location and size of local government units, available resources and natural values, investment attractiveness) and may also be independent of it (e.g. economic fluctuations in the country and in the world, the state of public finances, income and expenditure management of LGUs) (Rodríguez Bolívar et al., 2016; Cabaleiro-Casal et al., 2013).

Financial independence should be understood as a specific scope of decision-making independence of municipalities in the context of the 
possibility of conducting their own fiscal policy in a given area (Poniatowicz, 2015). It is reflected in giving municipalities a separate organizational structure, legal personality and, consequently, granting them municipal property, ensuring financial independence for municipalities (Stępień, 2006).

Financial independence of communes in the Świętokrzyskie Voivodeship

The conducted research showed the diversification of the level of financial independence of communes in the Świętokrzyskie Voivodeship. In 2018, the OE measure of financial independence ranged from 0.49 Sitkówka-Nowiny (2) (the best unit) to 0.91 Bieliny (2) - the weakest unit, and in 2009 from 0.49 SitkówkaNowina (2) to 0.93 Stupia Konecka (2). The range of values adopted by the OE measure in 2009, the values were higher (range 0.44) than in 2018 (range 0.42).

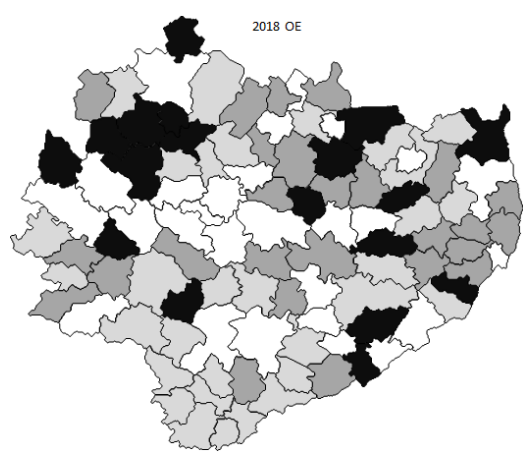

OE financial independence

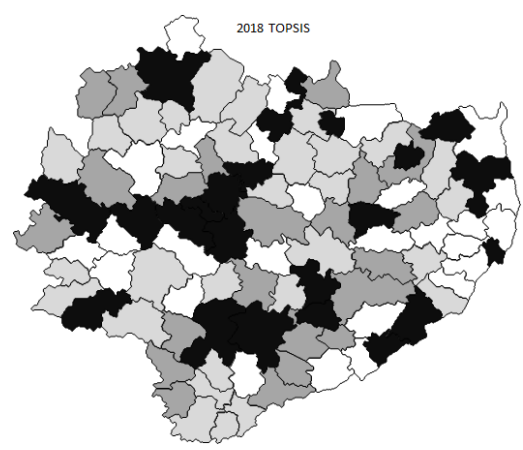

TOPSIS financial independence

$$
\text { gr I }
$$$$
\text { gr II }
$$

gr III

gr IV

Figure 1. Spatial differentiation of the financial independence of municipalities in the Świętokrzyskie Voivodeship in 2018 Source: own study based on the data of the Central Statistical Office of Poland

The TOPSIS measure of the financial situation ranged from 0.11 Oksa (2) (the weakest unit) to 0.58 Sitkówka-Nowiny (2) (the best unit) in 2018, and from 0.08 Słupia Konecka (2) to 
0.57 Sitkówka - Nowiny (2) in 2009. There is also a decrease in the range in 2018 (0.47) in relation to 2009 (0.49) (Figure 1).

Financial independence was correlated with own income, income from local taxes, share in income from PIT and CIT, subsidies and subsidies. These factors indicate the possibility of generating income and may be a determinant of development. The level of expenditure independence was also shaped by the number of employed and unemployed persons, natural persons and entities conducting economic activity as well as synthetic measures of the financial situation, entrepreneurship and development.

\section{Summary}

The local government carries out many tasks influencing the state of development of the commune and the standard of living of its inhabitants. It is very important to know, evaluate and correctly interpret financial phenomena.

The assessment of financial independence is important from the point of view of the efficiency of municipalities. The distribution of the assessment of financial independence of municipalities in the Świętokrzyskie Voivodeship was spatially polarized.

The obtained results indicate that a higher level of financial independence is related to a better financial situation, a higher level of development and a lower share of transfers from the state budget.

Local authorities should first of all take care to improve the economic potential, which will increase the attractiveness of the area and attract new entrepreneurs and improve the quality of life of the inhabitants.

\section{References:}

1. Behzadian M., Khanmohammadi Otaghsara S., Yazdani M., Ignatius J. (2012) A state-of the-art survey of TOPSIS applications. Expert Systems with Applications, no. 39(17).

2. Cabaleiro-Casal R., Buch-Gómez E.J., Vaamonde Liste A. (2013) Developing a Method to Assessing the Municipial Financial Health. American Reviev of Public Administration, no. 43(6).

3. Dziekański P., Pawlik A. (2019) Intraregional diversification of the level of the financial situation of the poviats of Eastern Poland in relation to the development potential. Baltic Journal of Economic Studies, vol. 5, no. 3. 
4. Dziekański P., Pawlik A., Wrońska M., Karpińska U. (2020) Demographic potential as the basis for spatial differentiation of the financial situation communes of Eastern Poland in 2009-2018. European Research Studies Journal, vol. 23 no. spec. 2.

5. Dziekański P., Prus P. (2020) Financial diversity and the development process: Case study of rural communes of Eastern Poland in 2009-2018. Sustainability, vol. 12 , no. 16 .

6. Dziemianowicz R.I., Kargol-Wasiluk A., Bołtromiuk A. (2018) Samodzielność finansowa gmin w Polsce w kontekście koncepcji good governance. Optimum. Economic Studies, no. 4 (94).

7. Kukuła K. (2000) Metoda unitaryzacji zerowanej. Warszawa: Wydawnictwo Naukowe PWN.

8. Malina A. (2004) Wielowymiarowa analiza przestrzennego zróżnicowania struktury gospodarki Polski wedtug województw. Kraków: Wyd. Akademii Ekonomicznej w Krakowie.

9. Poniatowicz M. (2015) Determinanty autonomii dochodowej samorządu terytorialnego w Polsce. Nauki o Finansach, no. 1(22).

10. Rodríguez Bolívar M.P., Navarro Galera A., Alcaide Muñoz L., López Subirés M.D. (2016) Risk Factors and Drivers of Financial Sustainability in Local Government: An Empirical Study. Local Government Studies, vol. 42(1).

11. Stanny M., Strzelczyk W. (2018) Kondycja finansowa samorzadów lokalnych a rozwój społeczno-gospodarczy obszarów wiejskich. Ujęcie przestrzenne. Warszawa: Wydawnictwo Naukowe SCHOLAR.

12. Stępień H. (2006) Finanse lokalne $w$ warunkach decentralizacji finansów publicznych. Włocławek; Wyższa Szkoła Humanistyczno-Ekonomiczna.

13. Szubrycht T. (2006) Wspólczesne aspekty bezpieczeństwa państwa. ZN Akademii Marynarki Wojennej, XLVII NR 4 (167). 